\title{
Pengembangan Pribadi Guru PAK dan Siswa Sekolah Dasar Nekbaun
}

\author{
Wardana Kussuma \\ Institut Agama Kristen Negeri Palangka Raya \\ Email:wardana_50@yahoo.com \\ Leksias Henuk \\ Sekolah Dasar Negeri Nekbaun \\ Email: henukleksi@gmail.com
}

\begin{abstract}
:
This research intends to describe the personality of Christian Education teachers as a model of student personality development. The personality of the teacher is the essential nature of a teacher that is reflected and can be seen in everyday attitudes. It can be seen and exemplified by students. The method used in this study is qualitative descriptive. The data collected is interviews and documentation. The results showed that interview studies of PAK teacher respondents generally showed that PAK teachers have good personalities. This good personality provides good examples for students as well. Good example is in the form of transparency in terms of dressing, speaking, behaving and behaving well in everyday life in the classroom, school environment, and in the community environment. Furthermore, the analysis of interview research results to respondents of class $V$ of Nekbaun State Elementary School showed that generally respondents gave good assessment.
\end{abstract}

Keywords: personality; teacher; students; christian religious education; nekbaun

\begin{abstract}
Abstrak:
Penelitian ini bermaksud untuk mendeskripsikan keperibadian guru Pendidikan Agama Kristen sebagai model pengembangan kepribadian siswa. Kepribadian guru merupakan sifat hakiki dari seorang guru yang tercermin dan dapat dilihat dalam sikap sehari-hari. Hal ini dapat dilihat dan dicontoh oleh siswa. Metode yang digunakan dalam penelitian ini ialah deskriptif kualitatif. Pengumpulan data yang digunakan ialah wawancara dan dokumentasi. Hasil penelitian menunjukkan bahwa penelitian wawancara responden guru PAK umumnya menunjukkan bahwa guru-guru PAK memiliki kepribadian yang baik. Kepribadian yang baik ini memberikan keteladanan yang baik juga bagi siswa. Keteladanan baik itu berupa keteladanan dalam hal berbusana, berkata-kata, bersikap dan berperilaku baik dalam kehidupan sehari-hari di kelas, lingkungan sekolah, serta di lingkungan masyarakat. Selanjutnya analisa hasil penelitian wawancara kepada responden siswa kelas V SD Negeri Nekbaun menunjukkan bahwa umumnya responden memberikan penilaian baik.
\end{abstract}

Kata Kunci: kepribadian; guru; siswa; pendidikan agama Kristen; Nekbaun 


\section{Pendahuluan}

Guru merupakan sosok yang akan diteladani oleh murid-muridnya, sehingga segala sikap, tingkah laku, dan pribadinya harus dijaga. Dalam kenyataannya untuk saat ini kondisi guru belum seperti yang diharapkan. Pada tahun 2004 hanya $43 \%$ guru memenuhi syarat, artinya sebagian besar guru (57\%) tidak memenuhi syarat, tidak kompeten, dan tidak profesional. ${ }^{1}$ Lebih lanjut dikatakan bahwa sedikitnya ada tiga syarat utama yang harus diperhatikan dalam peningkatan kualitas sumberdaya manusia, yakni: saranagedung, buku yang berkualitas, guru dan tenaga kependidikan yang profesional.

Lebih lanjut, menurut Suyanto dan Asep Jihad bahwa untuk menjadi guru, seseorang harus memiliki kepribadian yang kuat dan terpuji. ${ }^{2} \mathrm{Hal}$ ini penting karena kepribadian guru mempunyai pengaruh langsung terhadap hidup dan kebiasaankebiasaan belajar siswa. Lebih lanjut Suyanto dan Asep mengatakan bahwa sejumlah percobaan dan hasil-hasil observasi menguatkan kenyataan bahwa banyak sekali yang dipelajari oleh siswa dari gurunya. Siswa akan menyerap sikap-sikap, merefleksikan perasaan-perasaan, menyerap keyakinan-keyakinan, meniru tingkah laku, dan mengutip pernyataan-pernyataan gurunya. Pengalaman menunjukkan bahwa masalah-masalah seperti motivasi, disiplin, tingkah laku sosial, prestasi, dan hasrat belajar yang terus-menerus pada diri siswa yang bersumber dari kepribadian guru.

Penjelasan Suyanto dan Asep di atas menunjukkan bahwa kepribadian guru berpengaruh pada siswa. Terlebih dalam hal membentuk kepribadian siswa. Hal ini sejalan dengan kompetensi guru yang tertuang dalam Penjelasan Peraturan Pemerintah No. 19 Tahun 2005 tentang Standar Nasional Pendidikan. Dimana kompetensi yang mesti dimiliki oleh seorang guru adalah kompetensi pedagogik, kepribadian, sosial, dan profesional. Salah satunya yang dibahas dalam tulisan ini adalah tentang kompetensi kepribadian.

Kompetensi kepribadian dalam tulisan ini erat kaitannya dengan kompetensi guru Pendidikan Agama Kristen (PAK). Dimana keribadian guru PAK diharapkan dapat mengatasi masalah-masalah kepribadian siswa khususnya di kelas V SD Negeri Nekbaun Amarasi Barat. Masalah-masalah yang terjadi di sekolah ini antara lain: guru belum sepenuhnya memberikan teladan yang baik kepada siswa. Keteladanan itu seperti perkataan guru yang kasar kepada siswa, terlambat masuk kelas pada jam pelajaran, kurang peduli pada kesulitan belajar siswa, tidak mau dikritik oleh siswa, dan sebagainya.

Masalah lainnya adalah perilaku guru yang tidak memberikan keteladanan membawa dampak yang buruk bagi siswa. Misalnya: siswa tidak terlalu memperhatikan penjelasan dari guru ketika mengajar dan memberikan materi pembelajaran di kelas. Kemudian, ada siswa yang suka terlambat masuk kelas. Siswa suka membuat keributan di kelas dengan mengganggu teman-temannya yang lain dengan melempar gulungan kertas atau mengganggu dengan kata-kata yang menjelek-jelekan. Bahkan bisa berdampak pada perilaku siswa di luar sekolah, misalnya siswa jadi malas belajar. Rumusan masalah dalam penelitian ini adalah

${ }^{1}$ E. Mulyana, Menjadi Guru Profesional (Bandung: Remaja Rosdakarya, 2006).

${ }^{2}$ Suyanto dan Asep Jihad, Menjadi Guru Profesional: Strategi Meningkatkan Kualifikasi dan Kualitas Guru di Era Global (Jakarta: Erlangga, 2013), 15. 
sebagai berikut Bagaimana cara efektif guru dalam mengembangkan kepribadian siswa? Kemudian, solusi apa yang diberikan oleh guru sehingga siswa bisa belajar efektif? Sehingga tujuan dari penelitian ini ialah untuk mengetahui cara efektif guru dalam mengembangkan kepribadian siswa, serta untuk mengetahui solusi dari guru agar siswa dapat belajar efektif.

\section{Medote}

Penelitian ini menggunakan metode deskriptif kualitatif. Informan terdiri atas 3 orang guru PAK serta 27 orang siswa kelas V SD Negeri Nekbaun. Penelitian ini mengkaji aspek kepribadian guru PAK dan kepribadian siswa. Metode pengumpulan data yang digunakan dalam penelitian ini adalah wawancara dan dokumentasi. Data yang dikumpulkan akan dianalisis dengan teknik deskriptif kualitatif. Hasil analisis tersebut menjadi hasil kesimpulan dari penelitian ini.

\section{Hasil dan Pembahasan}

\section{Kepribadian Guru Agama Kristen}

Menurut Kamus Besar Bahasa Indonesia (KBBI) kata "kepribadian" memiliki arti yaitu sifat hakiki yang tercermin pada sikap seseorang atau suatu bangsa yang membedakannya dari orang atau bangsa lain. Dengan kata lain, kepribadian adalah sifat hakiki yang tercermin pada sikap seseorang yang membedakannya dengan orang lain. Menurut Purwanto, kepribadian atau personality berasal dari bahasa Latin, yaitu personare yang berarti mengeluarkan suara (to sound trough). ${ }^{3}$ Istilah ini digunakan untuk menunjukkan suara dari percakapan seorang pemain sandiwara melalui topeng (masker) yang dipakainya.

Lebih lanjut Surya menjelaskan kepribadian secara etimologis. ${ }^{4}$ Berikut penjelasannya: Istilah kepribadian merupakan terjemahandari istilah dalam bahasa Inggris yaitu personality.Istilah ini berasal dari bahasa Latin yaitu kata per dan sonare yang berarti topeng (mask) yang dipakai oleh para pemain sandiwara. Tetapi istilah personality juga berasal dari kata persona yang berarti pemain sandiwara (aktor), yaitu orang yang memakai topeng pada waktu bermain sandiwara. Dengan demikian asal kata istilah personality mempunyai dua pengertian yaitu berarti pemain sandiwara (actor) atau dapat pula berarti topeng atau mask yang dipakai oleh pemain sandiwara. Jadi personality dapat ditafsirkan sebagai suatu perwujudan perilaku seseorang yang mungkin sebagai perilaku yang sebenarnya (substansi) atau yang tidak sebenarnya (memakai topeng).

Selanjutnya adalah pengertian guru. Menurut Djamarah, guru adalah figur seorang pemimpin yang merupakan sosok arsitektur yang dapat membentuk jiwa dan watak anak didik. ${ }^{5}$ Lebih lanjut ia mengatakan bahwa guru mempunyai kekuasaan untuk membentuk dan membangun kepribadian anak didik menjadi seorang yang berguna bagi agama, nusa, dan bangsa. Dari penjelasan-penjelasan tersebut, dapat

\footnotetext{
${ }^{3}$ Ngalim Purwanto, Psikologi Pendidikan (Bandung: Remaja Rosda Karya, 1990), 15.

${ }^{4}$ Mohamad Surya, Psikologi Guru: Konsep dan Aplikasinya (Bandung: Alfabeta, 2014), 83.

5 Syaiful Bahri Djamarah, Guru dan Anak Didik dalam Interaksi Edukatif: Suatu Pendekatan Teoritis Psikologis (Jakarta: Rineka Cipta, 2010), 36.
} 
ditarik kesimpulan bahwa kepribadian guru adalah sifat hakiki dari seorang guru yang tercermin dan dapat dilihat dalam sikap sehari-hari.

Kepribadian guru memiliki beberapa ciri. Ciri kepribadian guru dapat dijelaskan sebagai berikut. Menurut Suyanto dan Asep, seorang guru harus memiliki kepribadian yang kuat dan terpuji. ${ }^{6}$ Kepribadian yang kuat dan terpuji itu tercermin dalam ciri kepribadian seperti: kepribadian yang mantap dan stabil, dewasa, arif, dan berwibawa. Kepribadian yang mantap dan stabil memiliki indikator esensial, yaitu: bertindak sesuai dengan norma hukum dan norma sosial, bangga sebagai guru, dan memiliki konsistensi dalam bertindak dan berperilaku. Kepribadian yang dewasa memiliki indikator esensial, yaitu: menampilkan kemandirian dalam bertindak sebagai pendidik dan memiliki etos kerja sebagai guru. Kepribadian yang arif memiliki indikator esensial, yaitu: menampilkan tindakan yang didasarkan pada kemanfaatan siswa, sekolah, dan masyarakat serta menunjukkan keterbukaan dalam berpikir dan bertindak. Kepribadian yang berwibawa memiliki indikator esensial, yaitu: memiliki perilaku yang berpengaruh positif terhadap proses dan hasil belajar siswa, perilaku yang disegani dan berakhlak mulia yang bertindak sesuai dengan norma agama (iman dan takwa, jujur, ikhlas, suka menolong), dan perilaku yang diteladani siswa.

Berikutnya ialah kualitas kepribadian guru profesional. Pada bagian ini akan dipaparkan kualitas kepribadian yang mesti dimiliki oleh guru yang profesional. Kualitas kepribadian ini dikutip oleh Mohamad Surya dari buku karya Cavanag, Michael E. Kualitas kepribadian yang harus dimiliki oleh seorang guru yang profesional itu adalah sebagai berikut: ${ }^{7}$

a. Pengetahuan mengenai diri sendiri

Pengetahuan mengenai diri sendiri yaitu seorang guru harus mengetahui tentang dirinya sendiri, apa yang sedang dilakukan, permasalahan apa yang sedang dihadapi. Hal ini penting karena seorang guru yang mengetahui persepsi dirinya dengan baik cenderung untuk mengetahui persepsi diri siswa yang menjadi peserta didiknya.

b. Kecakapan

Pada bagian ini seorang guru harus memiliki kualitas baik, intelektual, emosional, sosial, dan moral yang penting untuk dapat membantu klien. Kemampuan ini sangat penting bagi seorang guru, siswa yang menjadi asuhannya menginginkan dapat hidup lebih efektif dan bahagia.

c. Kesehatan psikologis yang baik

Seorang guru harus menjadi model kesehatan psikologis. Mereka harus lebih sehat dari pada orang yang mereka temui dalam proses pembelajaran. Kesehatan psikologis yang baik seorang guru sangatlah penting, karena akan mendasari pemahaman perilaku dan keahlian mereka, terutama dalam membentuk suatu kekuatan positif dalam pembelajaran.

\footnotetext{
${ }^{6}$ Suyanto dan Jihad, Menjadi Guru Profesional.

7 Surya, Psikologi Guru, 254-275.
} 


\section{d. Dapat dipercaya}

Kepercayaan sangatlah penting bagi seorang guru dengan alasan: untuk mendorong orang menjadi dirinya sendiri dan dalam membangun kepercayaan diri guru maupun siswa.

e. Kejujuran

Kejujuran yang absolute berarti bahwa seorang guru harus transparan dan sejati. Karakteristik ini sangat penting mengingat bahwa transparansi memudahkan guru dan siswanya berinteraksi sedekat mungkin.

f. Kekuatan

Kekuatan merupakan titik tengah antara intimidasi dan kelemahan. Hal ini dibutuhkan bagi seorang guru untuk memberi kemungkinan siswa merasa aman. Para guru memerlukan kekuatan dalam mengatasi serangan psikologis dam manipulasi yang dilakukan oleh siswa.

g. Kehangatan

Kehangatan mempunyai makna sebagai sesuatu yang baik, perhatian dan dapat menghibur orang lain. Kehangatan dalam berkomunikasi biasanya secara nonverbal melalui nada suara, ekspresi mata, dan mimik wajah. Kehangatan sangatlah penting dalam pembelajaran, karena dapat mencairkan suasana.

h. Pendengar yang aktif

Guru diharapkan mampu secara dinamis terlibat dengan proses pembelajaran. Mendengarkan dengan baik adalah titik tengah antara hiperaktif dan kebingungan, menjadi orang yang pasif dan ngantuk. Bagi seorang guru kualitas ini sangat penting karena menunjukkan perhatian secara personal dan juga menstimulus siswa untuk bereaksi secara spontan pada guru.

i. Kesabaran

Guru dapat membangun situasi yang dapat dikembangkan secara alami, tanpa secara premature memberikan gagasan pribadi, perasaan, atau nilai-nilai. Kesabaran memperkenankan seseorang dalam berkonsultasi akan menciptakan situasi yang kondusif.

j. Kepekaan

Sensitivitas dalam diri guru sangat penting karena mereka harus berkomunikasi dengan siswa. Siswa yang berkomunikasi dengan guru yang mempunyai sensitivitas akan merasakan lebih percaya diri. Guru yang sensitif memahami bagian-bagian dasar perasaan seseorang dan dapat mengangkat masalah-masalah ke kepermukaan.

k. Kebebasan

Kebebasan juga membawa seseorang yang sedang berkomunikasi akan lebih merasakan tali persaudaraan yang berarti apabila disertai rasa kebebasan. Salah satu hal yang harus diperhatikan adalah percaya diri untuk memilih pilihan-pilihan mereka dan memberikan kesempatan kepada orang lainuntuk berekspresi dengan bebas agar mereka mampu menciptakan suasana yang aman.

1. Kesadaran holistik

Kesadaran holistik guru dalam pembelajaran adalah bahwa guru menyadari keseluruhan orang dan tidak mendekati hanya dari satu aspek saja. Namun hal ini bukan berarti bahwa guru adalah seorang ahli dalam semua aspek, tetapi 
menyadari adanya beberapa dimensi seseorang dan bagaimana satu dimensi itu saling berkait.

Berkaitan dengan kualitas kepribadian guru profesional, Sidjabat (2009: 68-70) juga menjabarkan ciri khas guru PAK profesional sebagai berikut: ${ }^{8}$

1) Mampu memahami isi Alkitab secara baik dan benar.

2) Mampu menjembatani antara persoalan seharian yang dihadapi oleh peserta didik dengan berita Alkitab.

3) Menguasai prinsip-prinsip pendidikan.

4) Mampu mengelola program-program pembelajaran.

5) Mampu mengelola kelas.

6) Mampu membimbing dan mendampingi peserta didik dalam proses mencapai nilai-nilai kehidupan sebagai murid Yesus.

Pokok bahasan selanjutnya ialah aspek kepribadian siswa. Beberapa aspek dalam kepribadian siswa menurut Purwanto (1990:156-159) sebagai berikut:

a. Sifat-sifat kepribadian (personality traits), yaitu sifat-sifat yang ada pada individu, seperti: penakut, pemarah, suka bergaul, peramah, serta menyendiri.

b. Intelegensi kecerdasan temasuk di dalamnya kewaspadaan, kemampuan belajar, kecakapan berfikir.

c. Pernyataan diri dan cara menerima pesan-pesan.

d. Kesehatan jasmani.

e. Bentuk tubuh.

f. Sikapnya terhadap orang lain.

g. Pengetahuan, kualitas dan kuantitas pengetahuan yang dimiliki seseorang.

h. Keterampilan (skill).

i. Nilai-nilai yang ada pada seseorang dipengaruhi oleh adat istiadat, etika, kepercayaan yang dianutnya.

j. Penguasaan dan kuat lemahnya perasaan

k. Peranan (roles) adalah kedudukan atau posisi seseorang di dalam masyarakat di mana ia hidup.

1. The self, yaitu anggapan dan perasaan tertentu tentang siapa, apa, dan di mana sebenarnya ia berada.

Dari aspek-aspek yang diuraikan di atas, dapat digolongkan menjadi tiga bagian, yaitu: pertama, aspek-aspek kejasmanian. Aspek ini meliputi tingkah laku luar yang mudah tampak dan ketahuan dari luar, misalnya cara-cara berbuat, berbicara, dan sebagainya. Kedua, aspek-aspek kejiwaan, meliputi aspek-aspek yang tidak segera dapat dan diketahui dari luar, misalnya cara berfikir, sikap, dan minat. Ketiga, aspek- aspek kerohanian yang luhur, meliputi aspek-aspek kejiwaan yang lebih abstrak, yaitu filsafat hidup dan kepercayaan.

Kemudian juga diuraikan aktor-faktor yang mempengaruhi kepribadian siswa. Berikut ini terdapat beberapa faktor yang mempengaruhi kepribadian siswa:

a) Faktor biologis, yaitu yang berhubungan dengan keadaan jasmani yang meliputi keadaan pencernaan, pernapasan, peredaran darah, kelenjar-kelenjar urat syaraf, dan lain-lain.

${ }^{8}$ B. S. Sidjabat, Mengajar Secara Profesional Mewujudkan Visi Guru Profesional (Bandung: Kalam Hidup, 2009), 68-70. 
b) Faktor sosial, yaitu masyarakat yakni manusia-manusia lain di sekitar individu, adat istiadat, peraturan-peraturan, bahasa, dan sebagainya yang berlaku dalam masyarakat itu.

c) Faktor kebudayaan, yaitu kebudayaan itu tumbuh dan berkembang di dalam masyarakat dan tentunya kebudayaan dari tiap-tiap tempat yang berbeda akan berbeda pula kebudayaannya. Perkembangan dan pembentukan kepribadian dari masing-masing orang tidak dapat dipisahkan dari kebudayaan masyarakat di mana anak itu dibesarkan.

Sementara itu, faktor-faktor yang membentuk kepribadian siswa ada empat, yaitu: pertama, peranan cinta kasih dalam pembinaan kepribadian. Kedua, tidak menghina dan mengurangi hak anak. Ketiga, perhatian pada perkembangan kepribadian. Keempat, menghindari penggunaan kata kotor.

\section{Upaya Pembentukan Kepribadian Siswa}

Secara umum, kepribadian itu pada dasarnya dibentuk oleh pendidikan, karena pendidikan menanamkan tingkah laku yang kontinyu dan berulang-ulang sehingga menjadi kebiasaan. Indrakusuma, menegaskkan bahwa kepribadian itu dapat dibentuk oleh pendidikan, dan pendidikan itu sendiri bersumber pada tiga pusat pendidikan, yaitu lingkungan keluarga, sekolah, dan masyarakat. ${ }^{9}$

Menurut Marimba pembentukan kepribadian merupakan suatu proses yang terdiri atas tiga taraf, yaitu: ${ }^{10}$ pertama, pembiasaan. Pembiasaan ialah latihan-latihan tentang sesuatu supaya menjadi biasa. Pembiasaan hendaknya ditanamkan kepada anak-anak sejak kecil, sebab pada masa itu merupakan masa yang paling peka bagi pembentukan kebiasaan. Pembiasaan yang ditanamkan kepada anak-anak, itu harus disesuaikan dengan perkembangan jiwanya.

Kedua, pembentukan minat dan sikap. Dalam taraf kedua ini, pembentukan lebih dititikberatkan pada perkembangan akal (pikiran, minat, dan sikap atau pendirian). Pembentukan pada taraf ini terbagi dalam tiga bagian, yaitu: formil, materil, dan intensil. Aspek formil yaitu pembentukan secara formil, dilaksanakan dengan latihan secara berpikir, penanaman minat yang kuat, dan sikap (pendirian) yang tepat. Tujuan dari pembentukan formil ini adalah terbentuknya cara-cara berpikir yang baik, dapat menggunakan metode berpikir yang tepat, serta mengambil kesimpulan yang logis. Aspek materil yaitu pembentukan materil sebenarnya telah dimulai sejak masa kanak-kanak, jadi sejak pembentukan taraf pertama, namun barulah pada taraf kedua ini (masa intelek dan masa sosial). Anakanak yang telah cukup besar dan mampu menepis mana yang berguna dan mana yang tidak, harusnya dilatih berpikir kritis. Serta aspek intensil, yaitu pembentukan intensil yaitu pengarahan, pemberian arah, dan tujuan yang jelas dalam pendidikan yaitu terbentuknya kepribadian. Untuk membentuk ke arah mana kepribadian itu akan dibawa, maka di samping pemberian pengetahuan juga tentang nilai-nilai. Jadi, bukan hanya merupakan pemberian perlengkapan, tetapi juga pemberian tujuan ke arah mana perlengkapan itu akan dibawa.

\footnotetext{
${ }^{9}$ Amir Daien Indrakusuma, Pengantar Ilmu Pendidikan (Surabaya: Usaha Nasional, 1973), 108.

${ }^{10}$ Ahmad D. Marimba, Pengantar Filsafat Pendidikan Islam (Bandung: PT. Al-Ma'arif, 1989), 88.
} 


\section{Pembahasan}

Analisa data penelitian ini diperoleh dari pengolahan data hasil wawancara guru PAK dan hasil olah data wawancara siswa kelas V SD Negeri Nekbaun, Amarasi Barat. Analisa akan dilakukan dengan mendeskripsikan hasil pengolahan data yang diperoleh dari tiap-tiap pertanyaan. Baik pertanyaan wawancara untuk guru maupun untuk siswa.

\section{Analisa dan Pembahasan Hasil Wawancara Guru PAK}

Wawancara mendalam yang dilakukan kepada 3 responden guru PAK terdiri atas 5 pertanyaan. Jawaban dari masing-masing responden dapat dilihat pada tabel hasil wawancara guru di atas. Adapun analisa dan pembahasan dari setiap jawaban atas pertanyaan kepada responden tersebut adalah sebagai berikut: Pertanyaan pertama: Bagaimana pendapat bpk/ibu tentang keteladanan guru PAK dalam hal berbusana sehari-hari di dalam kelas? Jawaban dari ketiga responden peneliti rangkum menjadi jawaban sebagai berikut: keteladanan guru PAK dalam hal berbusana sehari-hari di kelas sudah baik. Hal ini didasari dengan jawaban responden yang menegaskan bahwa guru PAK sudah sewajarnya menjadi teladan dalam hal berbusana, yaitu menggunakan pakaian yang rapi dan sopan ketika mengajar di kelas. Aspek yang terpenting dalam berbusana adalah tidak berdampak negatif pada siswa.

Pertanyaan kedua, bagaimana pendapat bpk/ibu tentang keteladanan guru PAK dalam hal berbicara dengan siswa di kelas? Jawaban dari ketiga responden peneliti rangkum menjadi jawaban sebagai berikut: keteladanan guru PAK dalam hal berbicara dengan siswa di kelas sudah baik. Hal ini didasari dengan jawaban responden yang menegaskan bahwa guru PAK seharusnya dapat menjaga perkataannya ketika mengajar di kelas.Terutama menjaga agar perkataan guru tidak berdampak negatif bagi siswa. Sebab siswa terkadang suka meniru perkataan dari guru di kelas. Untuk itu, guru PAK perlu memperhatikan keteladanan dalam hal berbicara kepada siswa.

Pertanyaan ketiga, menurut bpk/ibu apakah guru PAK memberikan teladan yang baik bagi siswa dalam hal sikap dan perilaku di kelas? Jawaban dari ketiga responden peneliti rangkum menjadi jawaban sebagai berikut: guru PAK telah memberikan keteladanan yang baik bagi siswa dalam hal sikap dan perilaku di kelas. Hal ini didasari oleh jawaban responden yang menegaskan bahwa guru PAK harus bisa menjadi teladan dalam sikap dan perilaku. Guru memang tidak lepas dari kelemahan, akan tetapi guru harus bisa menjaga sikap dan perilakunya agar tetap baik. Untuk itu, guru PAK perlu berusaha menjaga agar sikap dan perilaku dapat menjadi teladan yang baik bagi siswa di kelas.

Pertanyaan keempat, bagaimana pendapat bpk/ibu tentang keteladanan guru PAK ketika berada di lingkungan sekolah? Jawaban dari ketiga responden peneliti rangkum menjadi jawaban sebagai berikut: Keteladan guru PAK ketika berada di lingkungan sekolah sudah baik. Hal ini didasari dengan jawaban responden yang menegaskan bahwa di sekolah guru agama dianggap dan menjadi figur yang dilihat oleh siswa, pegawai, maupun guru yang lainnya. Jadi, guru PAK harus menjadi teladan yang baik di sekolah. 
Pertanyaan kelima, bagaimana pendapat bpk/ibu tentang keteladanan guru PAK ketika berada di luar sekolah/masyarakat? Jawaban dari ketiga responden peneliti rangkum menjadi jawaban sebagai berikut: keteladanan guru PAK ketika berada di luar sekolah/masyarakat sudah baik. Hal ini didasari dengan jawaban responden yang menegaskan bahwa guru PAK dimana pun ia berada harus dapat menjadi teladan. Bukan hanya di sekolah, tetapi juga ketika ia berada di luar sekolah atau masyarakat. Terlebih guru agama seringkali menjadi sorotan di masyarakat. Untuk itu tidak ada alasan bagi guru agama untuk tidak menjadi teladan di masyarakat.

Jawaban-jawaban dari responden di atas dapat disimpulkan bahwa guru PAK dalam hal kepribadian telah memberikan keteladanan yang baik bagi siswa. Keteladanan itu baik dalam hal berbusana, perkataan, sikap dan perilaku yang tercermin dalam kehidupan sehari-hari di kelas, lingkungan sekolah, serta di lingkungan masyarakat.

\section{Analisa dan Pembahasan Hasil Wawancara Guru Umum}

Selanjutnya ialah wawancara kepada guru umum atau teman sejawat guru PAK. Guru umum yang dimaksud adalah guru Matematika dan guru Bahasa Indonesia. Peneliti melakukan wawancara kepada 2 responden guru umum ini. Wawancara terdiri atas 3 pertanyaan. Jawaban dari masing-masing responden dapat dilihat pada tabel hasil wawancara guru di atas. Adapun analisa dan pembahasan dari setiap jawaban atas pertanyaan kepada responden tersebut adalah sebagai berikut: pertama, bagaimana pendapat bpk/ibu tentang keteladanan guru PAK dalam hal berbusana sehari-hari di lingkungan sekolah? Jawaban dari duaorang responden, peneliti rangkum menjadi jawaban sebagai berikut: keteladanan guru PAK dalam hal berbusana sehari-hari di kelas umumnya sudah baik. Hal ini dikarenakan guru-guru PAK mengikuti atau mematuhi ketetapan yang sudah dikeluarkan oleh sekolah dalam hal berpakaian ketika mengajar di kelas.

Pertanyaan kedua, bagaimana pendapat bpk/ibu tentang keteladanan guru PAK dalam hal berbicara dengan siswa dan guru yang lainnya di lingkungan sekolah? Jawaban dari dua orang responden, peneliti rangkum menjadi jawaban sebagai berikut: keteladanan guru PAK dalam hal berbicara dengan guru lainnya umumnya sudah baik. Namun, ketika berbicara dengan siswa terkadang guru PAK berbicara kasar. Berbicara kasar disini bukan karena tidak ada alasan, akan tetapi karena ada alasan yaitu karena siswa membuat kesalahan atau nakal. Sekalipun demikian, guru PAK mesti dapat menjaga tutur katanya supaya tetap baik.

Pertanyaan ketiga, menurut bpk/ibu apakah guru PAK memberikan teladan yang baik bagi siswa dalam hal sikap dan perilaku di lingkungan sekolah? Jawaban dari dua orang responden, peneliti rangkum menjadi jawaban sebagai berikut: secara umum guru PAK telah memberikan keteladanan yang baik dalam sikap dan perilak. Namun berkaitan dengan disiplin masuk kelas, terkadang guru PAK masih ada yang suka terlambat masuk kelas. Sekalipun jarang, namun setidaknya dapat berpengaruh pada siswa.

Dari urian di atas, diperoleh gambaran bahwa guru PAK di mata pandangan guru-guru lainnya secara umum sudah baik dalam hal kepribadian. Sekalipun ada 
kelemahan itu hanya sebagian kecil saja. Misalnya, guru PAK terkadang berkata kasar kepada siswa yang membuat kesalahan dan nakal. Kemudian terkadang masih didapati ada guru PAK yang terlambat masuk kelas ketika jam pelajaran dimulai.

\section{Analisa dan Pembahasan Hasil Wawancara Siswa}

Analisa dan pembahasan hasil wawancara siswa ini dapat dilihat dari pengolahan data yang dimuat dalam tabel hasil wawancara siswa di atas. Pertanyaan yang diajukan kepada responden terdiri atas 20 pertanyaan. Dimana pertanyaan 1 sampai 10 berkaitan dengan kepribadian guru PAK serta pertanyaan 11 sampai 20 berkaitan dengan kepribadian siswa. Berikut ini analisa data dari tiap-tiap pertanyaan berdasarkan skala skor yang diperoleh dari hasil penelitian. Pertama, menurut Anda apakah Guru PAK sudah baik pada kegiatan awal pembelajaran memberikan salam, menyanyi dan berdoa? Pertanyaan satu ini diperoleh jawaban dari responden dengan skor sebesar 72dengan kategori penilaian Baik. Artinya, responden memberikan penilaian baik atas pernyataan bahwa guru PAK sudah baik pada kegiatan awal pembelajaran memberikan salam, menyanyi dan berdoa.

Kedua, menurut Anda apakah Guru PAK menyapa Anda dengan baik ketika masuk ke ruangan kelas? Pernyataan kedua ini diperoleh jawaban dari responden dengan skor sebesar 74 dengan kategori Baik. Artinya, responden memberikan penilaian baik atas pernyataan bahwa guru PAK menyapa siswa dengan baik ketika masuk ke ruangan kelas. Ketiga, menurut Anda apakah Guru PAK sudah baik dalam hal menegur Anda ketika salah? Pernyataan ketiga ini diperoleh jawaban dari responden dengan skor sebesar 72 dengan kategori Baik. Artinya, responden memberikan penilaian baik atas pernyataan bahwa guru PAK sudah baik dalam hal menegur siswa ketika melakukan kesalahan. Keempat, menurut Anda apakah Guru PAK sudah baik dalam hal berbusana di kelas? Pernyataan keempat ini diperoleh jawaban dari responden dengan skor sebesar 72 dengan kategori Baik. Artinya, responden memberikan penilaian baik atas pernyataan bahwa guru PAK sudah baik dalam hal berbusana di kelas.

Kelima, menurut Anda apakah Guru PAK sudah baik dalam hal memberikan sangsi di kelas? Pernyataan kelima ini diperoleh jawaban dari responden dengan skor sebesar 73 dengan kategori Baik. Artinya, responden memberikan penilaian baik atas pernyataan bahwa guru PAK sudah baik dalam hal memberikan sangsi pada siswa di kelas. Keenam, menurut Anda apakah Guru PAK sudah baik dalam hal memberikan bimbingan ketika anda berbuat kesalahan? Pernyataan keenam ini diperoleh jawaban dari responden dengan skor sebesar 73 dengan kategori Baik. Artinya, respoden memberikan penilaian baik atas pernyataan bahwa guru PAK sudah baik dalam hal memberikan bimbingan ketika siswa berbuat kesalahan. Ketujuh, menurut Anda apakah Guru PAK sudah baik dalam hal bersikap di kelas? Pernyataan ketujuh ini diperoleh jawaban dari responden dengan skor sebesar 73 dengan kategori Baik. Artinya, responden memberikan penilaian baik terhadap pernyataan bahwa guru PAK sudah baik dalam hal bersikap di kelas. Kedelapan, menurut Anda apakah Guru PAK sudah baik dalam hal bersikap di luar kelas? Pernyataan kedelapan ini diperoleh jawaban dari responden dengan skor sebesar 77 dengan kategori Baik. Artinya, 
responden memberikan penilaian baik atas pernyataan yang menegaskan bahwa guru PAK sudah baik dalam hal bersikap di luar kelas.

Kesembilan, menurut Anda apakah Guru PAK sudah baik dalam hal berkomunikasi dengan siswa di kelas? Pernyataan kesembilan ini diperoleh jawaban dari responden dengan skor sebesar 72 dengan kategori Baik. Artinya, responden memberikan penilaian baik atas pernyataan bahwa guru PAK sudah baik dalam hal berkomunikasi dengan siswa di kelas. Kesepuluh, apakah Guru PAK bagi Anda sudah baik dalam hal berkomunikasi dengan guru yang lainnya? Pernyataan kesepuluh ini diperoleh jawaban dari responden dengan skor sebesar 75 dengan kategori Baik. Artinya, responden memberikan penilaian baik atas pernyataan bahwa guru PAK sudah baik dalam hal berkomunikasi dengan guru yang lainnya. Kesebelas, Apakah Anda sudah baik dalam hal berprilaku di kelas? Pernyataan kesebelas ini diperoleh jawaban dari responden dengan skor sebesar 77 dengan kategori Baik. Artinya, responen memberikan penilaian baik atas pernyataan bahwa siswa sudah baik dalam hal berprilaku di kelas. Keduabelas, Apakah Anda sudah baik dalam hal tidak mencoret-coret meja di kelas? Pernyataan keduabelas ini diperoleh jawaban dari responden dengan skor sebesar 74 dengan kategori Baik. Artinya, responden memberikan penilaian baik atas pernyataan bahwa siswasudah baik dalam hal tidak mencoret-coret meja di kelas.

Ketigabelas, Apakah Anda sudah baik dalam menyapa guru ketika masuk kelas? Pernyataan ketigabelas ini diperoleh jawaban dari responden dengan skor sebesar 71 dengan kategori Baik. Artinya, responden memberikan penilaian baik atas pernyataan bahwa siswa sudah baik dalam menyapa guru ketika masuk kelas. Keempatbelas, Apakah Anda sudah baik dalam berbicara dengan sesama teman di kelas? Pernyataan keempatbelas ini diperoleh jawaban dari responden dengan skor sebesar 73 dengan kategori Baik. Artinya, responden memberikan penilaian baik atas pernyataan bahwa siswa sudah baik dalam berbicara dengan sesama teman di kelas. Kelimabelas, Apakah Anda sudah baik dalam hal tidak berkata-kata kotor di kelas? Pernyataan kelimabelas ini diperoleh jawaban dari responden dengan skor sebesar 69 dengan kategori Baik. Artinya, responden memberikan penilaian baik atas pernyataan bahwa siswasudah baik dalam hal tidak berkata-kata kotor di kelas. Keenambelas, Apakah Anda sudah baik dalam hal tidak ribut di kelas saat tidak ada guru? Pernyataan keenambelas ini diperoleh jawaban dari responden dengan skor sebesar 54 dengan kategori Cukup Baik. Artinya, responden memberikan penilaian cukup baik atas pernyataan bahwa siswa tidak ribut di kelas saat tidak ada guru. Dengan penilaian cukup baik menunjukkan bahwa siswa dalam beberapa kasus masih suka ribut di kelas ketika tidak ada guru.

Ketujuhbelas, Apakah Anda sudah baik dalam hal tidak membuang sampah sembarangan? Pernyataan ketujuhbelas ini diperoleh jawaban dari responden dengan skor sebesar 47 dengan kategori Cukup Baik. Artinya, responden memberikan penilaian cukup baik atas pernyataan bahwa siswa tidak membuang sampah sembarangan. Dengan penilaian cukup baik menunjukkan bahwa dalam beberapa kasus masih terdapat siswa yang membuang sampah sembarangan. Kedelapanbelas, Apakah Anda sudah baik dalam hal berpakaian rapi di kelas? Pernyataan kedelapanbelas ini diperoleh jawaban dari responden dengan skor sebesar 66 dengan 
kategori Cukup Baik. Artinya, responden memberikan penilaian cukup baik atas pernyataan bahwa siswa berpakaian rapi di kelas. Dengan penilaian cukup baik menunjukkan bahwa dalam beberapa kasus masih terdapat siswa yang berpakaian tidak rapi ketika masuk kelas. Kesembilanbelas, Apakah Anda sudah baik dalam hal menerima teman yang berbeda agama? Pernyataan kesembilanbelas ini diperoleh jawaban dari responden dengan skor sebesar 69 dengan kategori Baik. Artinya, responden memberikan penilaian baik atas pernyataan bahwa siswa sudah baik dalam hal menerima teman yang berbeda agama. Keduapuluh, Apakah Anda sudah baik dalam hal meneladai guru di kelas? Pernyataan satu ini diperoleh jawaban dari responden dengan skor sebesar 73 dengan kategori Baik. Artinya, responden memberikan penilaian baik atas pernyataan bahwa siswa sudah baik dalam hal meneladai guru di kelas.

Hasil analisa data penelitian di atas diperoleh keterangan bahwa variabel kepribadian guru PAK dari butir soal nomor 1-10 umumnya memperoleh penilaian kategori baik. Artinya, guru-guru PAK sudah menunjukkan kepribadian yang baik di lingkungan sekolah maupun di lingkungan masyarakat. Sementara itu, untuk variabel kepribadian siswa dari 10 pertanyaan terdapat 7 butir soal responden menjawab dan memberikan penilaian baik, serta 3 butir soal responden memberikan penilaian cukup baik. Penilaian baik itu terdapat pada butir soal nomor 11-15, 19 dan 20. Penilaian cukup baik terdapat pada butir soal nomor 16-18. Butir soal yang mendapat penilaian cukup baik ini berkaitan dengan aspek kepribadian siswa berupa: siswa dalam beberapa kasus masih suka ribut di kelas ketika tidak ada guru, siswa dalam beberapa kasus masih suka membuang sampah sembarangan, serta siswadalam beberapa kasus masih suka berpakaian tidak rapi ketika masuk kelas.

Keterangan di atas menunjukkan bahwa kepribadian guru PAK di SD Negeri Nekbaun, Amarasi Barat umumnya memperoleh penilaian baik. Penilaian baik ini berdampak positif pada perkembangan kepribadian siswa. Dimana kepribadian siswa pada umumnya juga memperoleh penilaian baik. Sekalipun demikian, dalam beberapa kasus masih terdapat kekurangan dalam kepribadian siswa.

\section{Implikasi}

Hasil penelitian ini memberikan implikasi pada upaya guru Pendidikan Agama Kristen untuk memperhatikan kepribadiannya dalam mengajar. Hal ini penting, oleh karena kepribadian guru dilihat secara langsun oleh siswa di sekolah maupun ketika berada di tengah-tengah masyarakat. Guru menjadi figur bagi siswa dalam bentuk sikap dan perilaku. Untuk itu, perhatian guru terhadap kepribadian sangat penting, terutama dalam upayanya dalam meningkatkan perkembangan kepribadian siswa di sekolah.

\section{Rekomendasi untuk Penelitian Lanjutan}

Penelitian ini lebih fokus pada kepribadian guru Pendidikan Agama Kristen di tingkat Sekolah Dasar dan hanya diteliti dalam satu sekolah. Penelitian selanjutnya yang dapat dilakukan oleh peneliti lain ialah dengan mengambil lokasi penelitian lebih luas dan menggunakan metode kuantitatif dengan populasi dan sampel yang 
lebih luas. Topiknya bisa saja sejenis, misalnya pengaruh kepribadian guru Pendidikan Agama Kristen terhadap pembentukan kepribadian siswa.

\section{Kesimpulan}

Analisa dan pembahasan hasil penelitian di atas, dibagi menjadi dua bagian yaitu analisa dan pembahasan hasil penelitian melalui instrumen wawancara mendalam kepada guru PAK, guru sejawat, dan instrumen wawancara terstruktur kepada siswa. Hasil analisa penelitian wawancara responden guru PAK umumnya menunjukkan bahwa guru-guru PAK memiliki kepribadian yang baik. Kepribadian yang baik ini memberikan keteladanan yang baik juga bagi siswa. Keteladanan baik itu berupa keteladanan dalam hal berbusana, berkata-kata, bersikap dan berperilaku baik dalam kehidupan sehari-hari di kelas, lingkungan sekolah, serta di lingkungan masyarakat.

Kemudian di mata guru-guru sejawat yang lainnya, diperoleh gambaran bahwa guru PAK secara umum sudah baik dalam hal kepribadian. Sekalipun ada kelemahan itu hanya sebagian kecil saja. Misalnya, guru PAK terkadang berkata kasar kepada siswa yang membuat kesalahan dan nakal. Kemudian terkadang masih didapati ada guru PAK yang terlambat masuk kelas ketika jam pelajaran dimulai. Selanjutnya analisa hasil penelitian wawancara kepada responden siswa kelas V SD Negeri Nekbaun menunjukkan bahwa umumnya responden memberikan penilaian baik kepada kepribadian guru PAK dan dalam beberapa kasus kerpibadian siswa memperoleh penilaian cukup baik. Aspek kepribadian siswa yang memperoleh cukup baik itu berupa: siswa dalam beberapa kasus masih suka ribut di kelas ketika tidak ada guru, siswa dalam beberapa kasus masih suka membuang sampah sembarangan, serta siswa dalam beberapa kasus masih suka berpakaian tidak rapi ketika masuk kelas. Analisa hasil penelitian melalui wawancara guru PAK dan siswa di atas dapat disimpulkan bahwa kepribadian guru PAK di SD Negeri Nekbaun, umumnya memperoleh penilaian baik berdampak positif pada perkembangan kepribadian siswa kelas V SD Negeri Nekbaun, Amarasi Barat.

\section{Rujukan}

Djamarah, Syaiful Bahri. Guru dan Anak Didik dalam Interaksi Edukatif: Suatu Pendekatan Teoritis Psikologis. Jakarta: Rineka Cipta, 2010.

Indrakusuma, Amir Daien. Pengantar Ilmu Pendidikan. Surabaya: Usaha Nasional, 1973.

Marimba, Ahmad D. Pengantar Filsafat Pendidikan Islam. Bandung: PT. Al-Ma'arif, 1989.

Mulyana, E. Menjadi Guru Profesional. Bandung: Remaja Rosdakarya, 2006.

Purwanto, Ngalim. Psikologi Pendidikan. Bandung: Remaja Rosda Karya, 1990.

Sidjabat, B. S. Mengajar Secara Profesional Mewujudkan Visi Guru Profesional. Bandung: Kalam Hidup, 2009.

Surya, Mohamad. Psikologi Guru: Konsep dan Aplikasinya. Bandung: Alfabeta, 2014. Suyanto dan Asep Jihad. Menjadi Guru Profesional: Strategi Meningkatkan Kualifikasi dan Kualitas Guru di Era Global. Jakarta: Erlangga, 2013. 